Nevada

Environmental

Restoration

Project

Streamlined Approach for

Environmental Restoration Plan

For Corrective Action Unit 408:

Bomblet Target Area

Tonopah Test Range, Nevada

Controlled Copy No.:

Revision: 0

October 2006

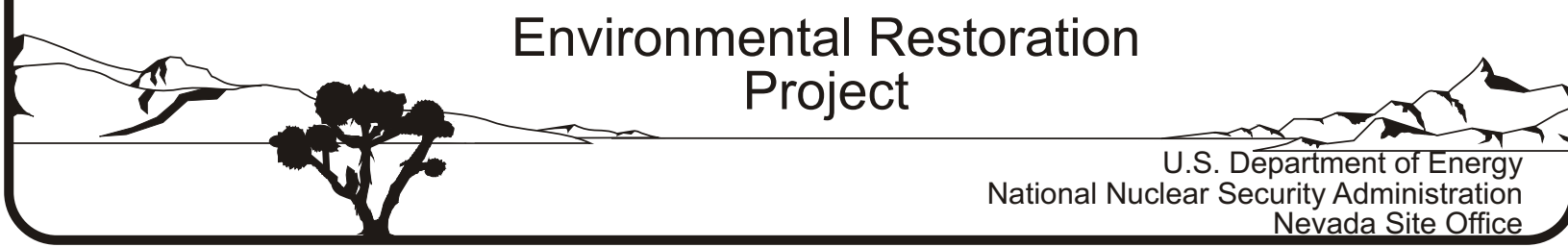




\section{DISCLAIMER}

Reference herein to any specific commercial product, process, or service by trade name, trademark, manufacturer, or otherwise, does not necessarily constitute or imply its endorsement, recommendation, or favoring by the U.S. Government or any agency thereof or its contractors or subcontractors.

This report has been reproduced directly from the best available copy.

Available for sale to the public from:

U.S. Department of Commerce

National Technical Information Service

5285 Port Royal Road

Springfield, VA 22161-0002

Telephone: (800) 553-6847

Fax: (703) 605-6900

E-mail: orders@ntis.gov

Online ordering: http://www.ntis.gov/ordering.htm

Available electronically at http://www.osti.gov/bridge.

Available for a processing fee to the U.S. Department of Energy and its contractors, in paper, from:

U.S. Department of Energy

Office of Scientific and Technical Information

P.O. Box 62

Oak Ridge, TN 37831-0062

Telephone: (865) 576-8401

Fax: (865) 576-5728

E-mail: reports@adonis.osti.gov 


\title{
STREAMLINED APPROACH FOR ENVIRONMENTAL RESTORATION PLAN FOR CORRECTIVE ACTION UNIT 408, BOMBLET TARGET AREA TONOPAH TEST RANGE, NEVADA
}

\author{
U.S. Department of Energy \\ National Nuclear Security Administration \\ Nevada Site Office \\ Las Vegas, Nevada
}

Controlled Copy No.

Revision: 0

October 2006 
THIS PAGE INTENTIONALLY LEFT BLANK 


\section{STREAMLINED APPROACH FOR ENVIRONMENTAL RESTORATION PLAN FOR CORRECTIVE ACTION UNIT 408, BOMBLET TARGET AREA TONOPAH TEST RANGE, NEVADA}

Kevin J. Cabble

Federal Sub-Project Director

Industrial Sites Sub-Project

Approved By: SIGNATURE APPROVED

Date: $\underline{10 / 23 / 2006}$

John B. Jones

Acting Federal Project Director

Environmental Restoration Project 
THIS PAGE INTENTIONALLY LEFT BLANK 


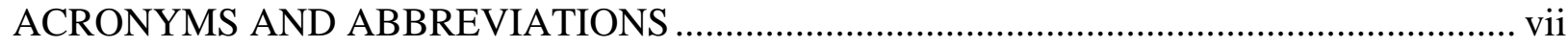

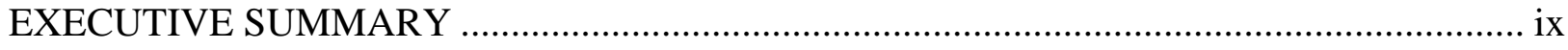

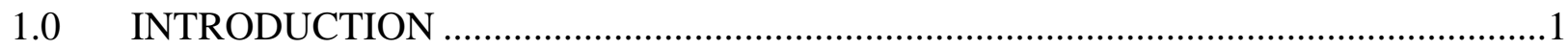

1.1 SAFER PROCESS .................................................................................

1.2 SumMARY OF PROPOSED CORRECTIVE ACTIONS ...............................................

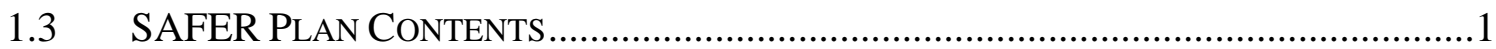

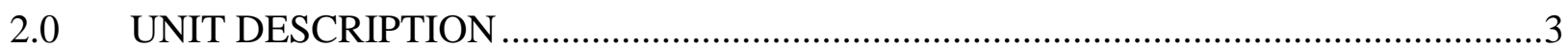

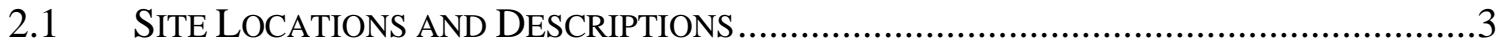

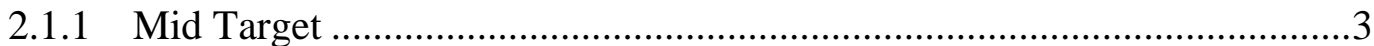

2.1.2 Flight Line Bomblet Location..........................................................

2.1.3 SAC Target ............................................................................

2.1.4 South Antelope Lake...................................................................

2.1.5 South Flight Line Tomahawk .........................................................5

2.2 HISTORY AND PROCESS KNOWLEDGE ..............................................................5

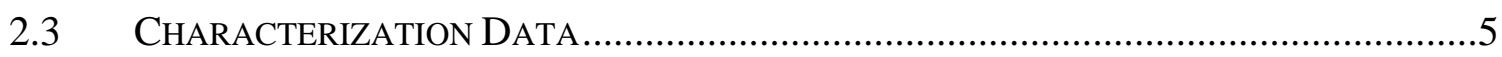

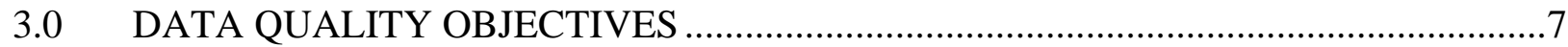

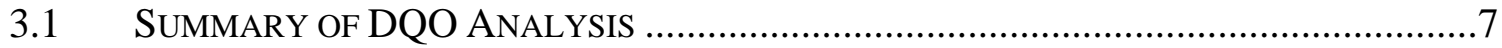

3.1.1 State the Problem (Step 1) ...................................................................

3.1.2 Identify the Goal of the Study (Step 2) .................................................10

3.1.3 Identify Information Inputs (Step 3) ....................................................11

3.1.4 Define the Boundaries of the Study (Step 4) ........................................12

3.1.5 Develop the Analytical Approach (Step 5) .............................................13

3.1.6 Specify Performance or Acceptance Criteria (Step 6) .............................14

3.1.7 Develop the Plan for Obtaining Data (Step 7) ........................................15

3.2 RESULTS OF THE DQO ANALYSIS ................................................................17

3.2.1 Action Level Determination and Basis .................................................17

3.2.2 Hypothesis Test................................................................................17

3.2.3 Statistical Model ....................................................................................17

3.2.4 Design Description/Option ...............................................................17

3.2.5 Conceptual Site Model......................................................................17

4.0 FIELD ACTIVITIES AND CLOSURE OBJECTIVES ..............................................19

4.1 CONTAMINANTS OF POTENTIAL CONCERN......................................................19

4.2 REMEDIATION ........................................................................................19

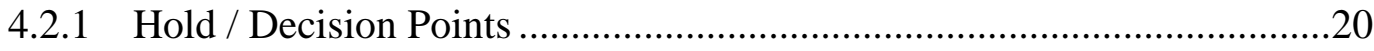

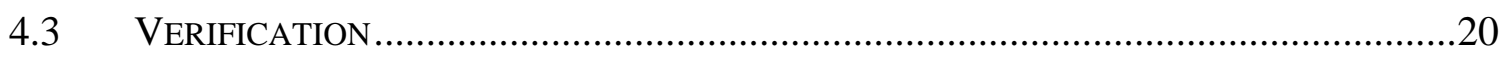

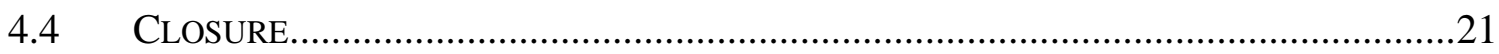

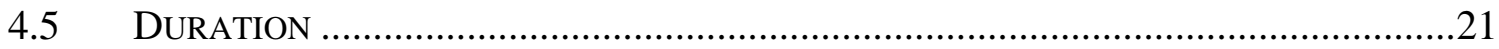




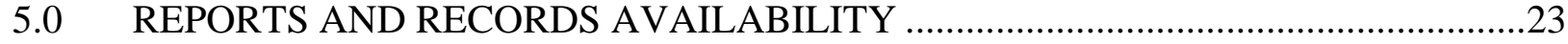

6.0 INVESTIGATION/REMEDIATION WASTE MANAGEMENT ...............................25

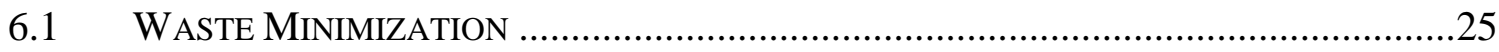

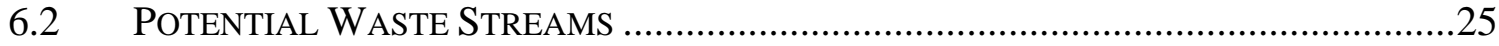

6.2.1 Sanitary Waste .............................................................................26

6.2.2 Low-Level Radioactive Waste..........................................................26

7.0 QUALITY ASSURANCE/QUALITY CONTROL …............................................27

7.1 SAMPLE COLLECTION ACTIVITIES.............................................................27

7.2 APPLICABLE LABORATORY/ANALYTICAL DATA QUALITY INDICATORS................27

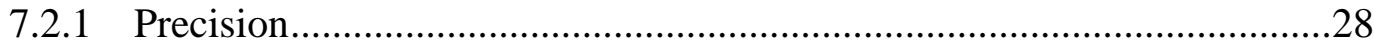

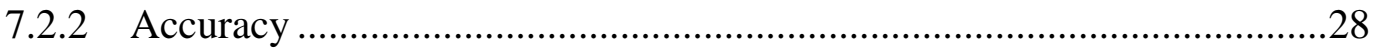

7.2.3 Representativeness ....................................................................29

7.2.4 Comparability .........................................................................29

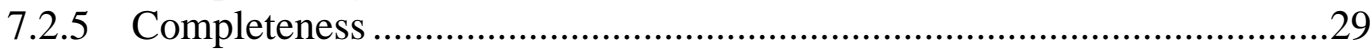

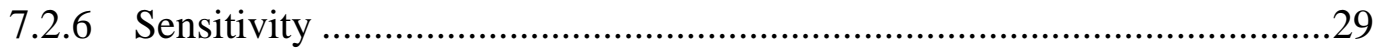

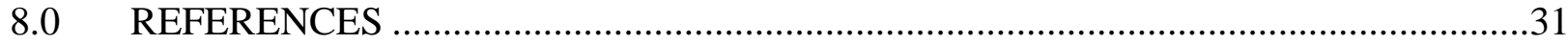

LIBRARY DISTRIBUTION LIST

\section{LIST OF FIGURES}

Figure 1. CAU 408 Bomblet TARget AREAS ......................................................................4

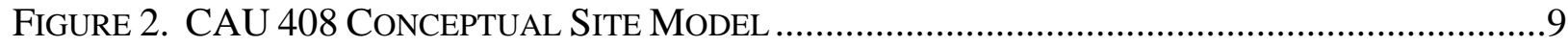

\section{LIST OF TABLES}

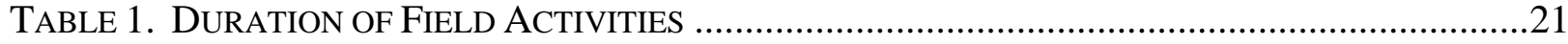

TABLE 2. LABORATORY/ANALYTICAL DATA QUALITY INDICATORS ........................................28

\section{APPENDICES}

Appendix A.1. Project ORganization 


\section{ACRONYMS AND ABBREVIATIONS}

\begin{tabular}{|c|c|}
\hline $\mathrm{BLU}$ & Bomb Live Unit \\
\hline CAS & Corrective Action Site \\
\hline CAU & Corrective Action Unit \\
\hline $\mathrm{CBU}$ & cluster bomb unit \\
\hline $\mathrm{COC}$ & contaminant of concern \\
\hline COPC & contaminant of potential concern \\
\hline CR & Closure Report \\
\hline CSM & conceptual site model \\
\hline $\mathrm{DOE} / \mathrm{NV}$ & U.S. Department of Energy, Nevada Operations Office \\
\hline DQI & data quality indicator \\
\hline DQO & data quality objective \\
\hline DU & depleted uranium \\
\hline EOD & explosive ordnance disposal \\
\hline EPA & U.S. Environmental Protection Agency \\
\hline FFACO & Federal Facility Agreement and Consent Order \\
\hline $\mathrm{ft}$ & foot (feet) \\
\hline $\mathrm{m}$ & meter(s) \\
\hline $\mathrm{mrem} / \mathrm{yr}$ & millirem(s) per year \\
\hline NDEP & Nevada Division of Environmental Protection \\
\hline NNSA/NSO & $\begin{array}{l}\text { U.S. Department of Energy, National Nuclear Security Administration Nevada } \\
\text { Site Office }\end{array}$ \\
\hline NNSA/NV & $\begin{array}{l}\text { U.S. Department of Energy, National Nuclear Security Administration Nevada } \\
\text { Operations Office }\end{array}$ \\
\hline NSTec & National Security Technologies \\
\hline NTS & Nevada Test Site \\
\hline NV/YMP & Nevada/Yucca Mountain Project \\
\hline $\mathrm{OI}$ & Organization Instruction \\
\hline PRG & Preliminary Remediation Goal \\
\hline QA & quality assurance \\
\hline QAPP & Quality Assurance Project Plan \\
\hline QC & quality control \\
\hline
\end{tabular}




\section{ACRONYMS AND ABBREVIATIONS (continued)}

$\begin{array}{ll}\text { ROTC } & \text { Record of Technical Change } \\ \text { RPD } & \text { relative percent difference } \\ \text { SAC } & \text { Strategic Air Command } \\ \text { SAFER } & \text { Streamlined Approach for Environmental Restoration } \\ \text { SDG } & \text { sample delivery group } \\ \text { TTR } & \text { Tonopah Test Range }\end{array}$


This Streamlined Approach for Environmental Restoration Plan provides the details for the closure of Corrective Action Unit (CAU) 408, Bomblet Target Area. CAU 408 is located at the Tonopah Test Range and is currently listed in Appendix III of the Federal Facility Agreement and Consent Order of 1996. One Corrective Action Site (CAS) is included in CAU 408:

- $\quad$ CAS TA-55-002-TAB2, Bomblet Target Areas

Based on historical documentation, personnel interviews, process knowledge, site visits, aerial photography, multispectral data, preliminary geophysical surveys, and the results of data quality objectives process (Section 3.0), clean closure will be implemented for CAU 408.

CAU 408 closure activities will consist of identification and clearance of bomblet target areas, identification and removal of depleted uranium (DU) fragments on South Antelope Lake, and collection of verification samples. Any soil containing contaminants at concentrations above the action levels will be excavated and transported to an appropriate disposal facility.

Based on existing information, contaminants of potential concern at CAU 408 include explosives. In addition, at South Antelope Lake, bomblets containing DU were tested. None of these contaminants is expected to be present in the soil at concentrations above the action levels; however, this will be determined by radiological surveys and verification sample results.

The corrective action investigation and closure activities have been planned to include data collection and hold points throughout the process. Hold points are designed to allow decision makers to review the existing data and decide which of the available options are most suitable. Hold points include the review of radiological, geophysical, and analytical data and field observations. 
SAFER Plan - CAU 408

Section: Executive Summary

Revision: 0

Date: October 2006

THIS PAGE INTENTIONALLY LEFT BLANK 


\subsection{INTRODUCTION}

This Streamlined Approach for Environmental Restoration (SAFER) Plan details the activities planned for the closure of Corrective Action Unit (CAU) 408, Bomblet Target Area. CAU 408 is located at the Tonopah Test Range (TTR) and is currently listed in Appendix III of the Federal Facility Agreement and Consent Order (FFACO, 1996). One Corrective Action Site (CAS) is included in CAU 408:

- $\quad$ CAS TA-55-002-TAB2, Bomblet Target Areas

\subsection{SAFER PROCESS}

CAUs that may be closed using the SAFER process have conceptual corrective actions that are clearly identified. Consequently, corrective action alternatives can be chosen prior to the completion of a corrective action investigation, given anticipated investigation results.

The SAFER process combines elements of the data quality objectives (DQOs) process and the observational approach to help plan and conduct corrective actions. DQOs are used to identify a problem and define the type and quality of data needed to complete the investigation phase of the process. The purpose of the investigation phase in the SAFER process is to verify the adequacy of existing information required to implement the corrective action. The observational approach provides a framework for managing uncertainty and planning decision-making.

\subsection{Summary of Proposed Corrective Actions}

Based on historical documentation, personnel interviews, process knowledge, site visits, aerial photography, multispectral data, preliminary geophysical surveys, and the DQOs (Section 3.0), closure of CAU 408 will be accomplished by clean closure. CAU 408 closure activities will consist of identification and clearance of bomblet target areas and removal of depleted uranium (DU) fragments located on South Antelope Lake. No contaminants of concern (COCs) are expected to be present in the soil at concentrations above the action levels; however, explosives and uranium have been identified as contaminants of potential concern (COPCs), and verification soil samples will be collected to verify whether these potential contaminants are above the action levels. If COCs are present, all soil containing COCs above action levels will be excavated and transported to an appropriate disposal facility.

\subsection{SAFER PLAN CONTENTS}

This SAFER Plan has been developed to support the closure of CAU 408 according to the required FFACO format, and includes the following:

- $\quad$ Section 1.0: Introduction

- $\quad$ Section 2.0: Unit Description

- $\quad$ Section 3.0: Data Quality Objectives 
- $\quad$ Section 4.0: Field Activities and Closure Objectives

- $\quad$ Section 5.0: Reports and Records Availability

- $\quad$ Section 6.0: Investigation/Remediation Waste Management

- $\quad$ Section 7.0: Quality Assurance / Quality Control

- $\quad$ Section 8.0: References

- $\quad$ Appendix A.1: Project Organization

This SAFER Plan was developed using guidance provided by the following documents:

- $\quad$ FFACO (FFACO, 1996)

- Industrial Sites Quality Assurance Project Plan (QAPP) (U.S. Department of Energy, National Nuclear Security Administration Nevada Operations Office [NNSA/NV], 2002)

- U.S. Environmental Protection Agency (EPA), Region IX Preliminary Remediation Goals (PRGs) (EPA, 2004)

- $\quad$ Nevada/Yucca Mountain Project (NV/YMP) Radiological Control Manual (U.S.

Department of Energy, Nevada Operations Office [DOE/NV], 2004) 


\subsection{UNIT DESCRIPTION}

CAU 408, Bomblet Target Area, is located on the TTR and includes several areas where bomblet drops were conducted from the late 1960s to 1985. A testing and development program for improved submunition dispersion coverage and cluster bomb unit (CBU) accuracy was conducted to map bomblet dispersion patterns, provide input for engineering design, and document the accuracy of laser-guided CBU pods. Submunitions consist of various types of small spherical and cylindrical ordnance that range in size from 2 to 4 inches. A submunition bomblet is defined as an intact ordnance item that was dispensed from a CBU. Dispersion testing included aerial drops of CBUs containing bomblets. After release from the aircraft, the CBUs would open and disperse the bomblets over the target areas. The bomblets used were mainly inert; however, several live tests (containing high explosives) were also conducted.

CAU 408 was originally identified as an approximately 18-square-mile area extending from Mid Lake to the middle of Antelope Lake. Recent records research, interviews with personnel, site visits, and geophysical surveys have reduced the investigation area to seven discrete locations where the actual bomblet testing occurred. The following submunition testing locations are known at this time:

- $\quad$ Mid Target

- $\quad$ Flight Line Bomblet Location

- $\quad$ Strategic Air Command (SAC) Target Location 1

- $\quad$ SAC Target Location 2

- $\quad$ South Antelope Lake

- $\quad$ South Flight Line Tomahawk Location 1

- $\quad$ South Flight Line Tomahawk Location 2

Figure 1 shows the bomblet target areas to be investigated.

\subsection{SITE LOCATIONS AND DESCRIPTIONS}

\subsubsection{Mid Target}

Mid Target, where a 1,000-foot (ft) by 1,500-ft CBU grid was constructed, was the primary location of bomblet testing at TTR. Known submunitions used at Mid Target include Bomb Live Unit (BLU)-61, BLU-63, BLU-97, and MK-118. One live test is known to have been conducted at Mid Target involving a submunition-containing fuel-air explosive device (BLU-72). Ordnance removed during previous field activities was disposed in a pit located west of Mid Target (CAU 400). The footprint of the Mid Target site is larger than the CBU grid due to long and short drops that missed the target. 


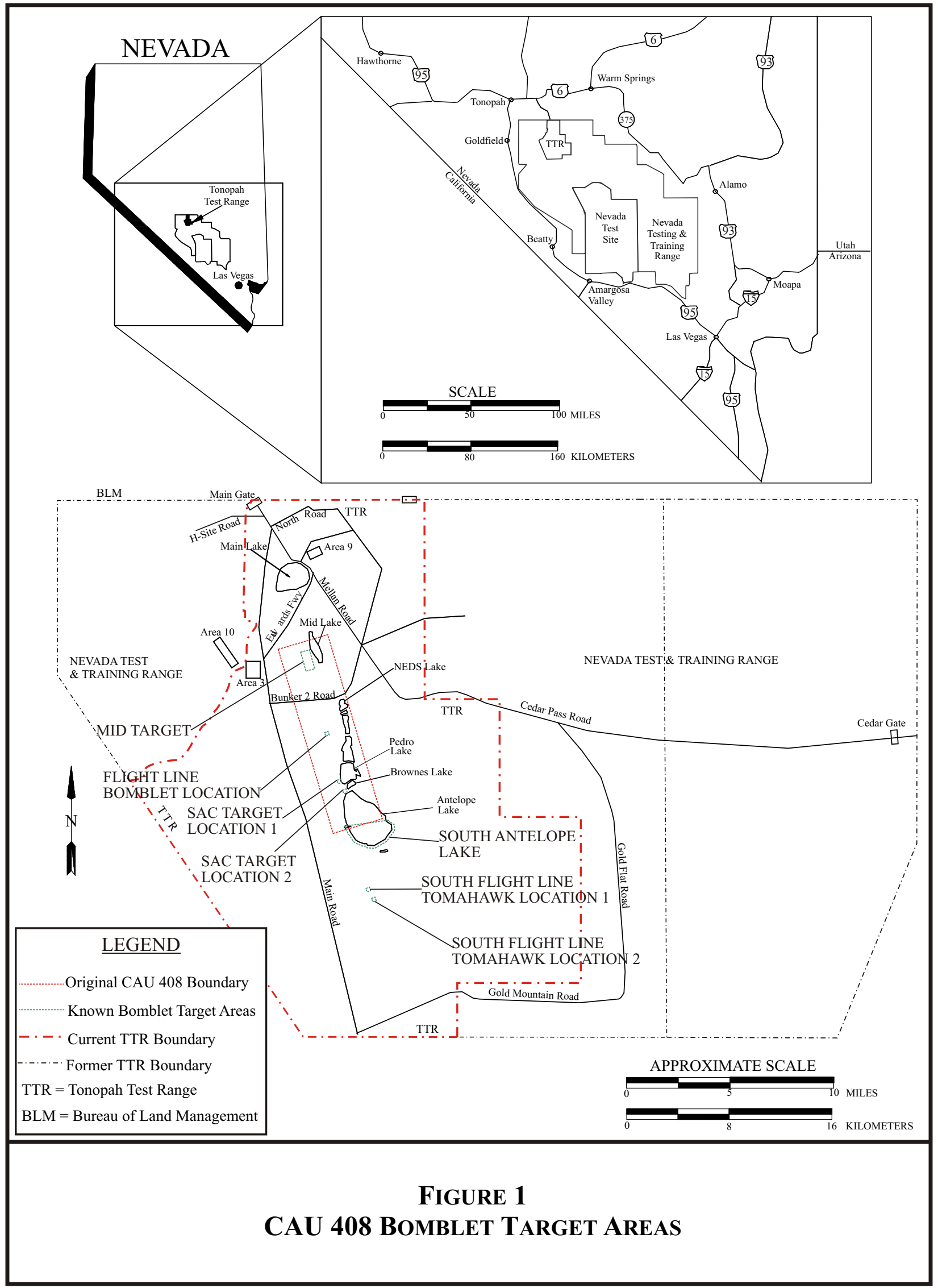




\subsubsection{Flight Line Bomblet Location}

The Flight Line Bomblet Location is located on the flight line between NEDS Lake and Pedro Lake, and contains BLU-63 bomblets. Some previous cleanup is evident, and field evaluation suggests a single drop of two CBUs at this location.

\subsubsection{SAC Target}

SAC Target is one of several locations at TTR where cruise-missile-dispensed bomblets were tested. Location 1 consists of an area of disturbed ground as well as a subsurface geophysical anomaly, possibly indicating an area of buried debris. Location 2 contains an unknown prototype bomblet or dispensing mechanism on the ground surface. The specific types of ordnance tested at the two SAC Target locations are unknown at this time. The two locations are believed to be related and will be managed as a single site.

\subsubsection{South Antelope Lake}

South Antelope Lake was the location of numerous tests involving BLU-26, BLU-49, BLU-63, BLU-97, MK-118, and prototype munitions/submunitions. Several of the tests involved full-scale live bomblet tests on test vehicles, and live prototype 40-millimeter grenades are present on South Antelope Lake. A prototype bomblet containing DU was also tested on South Antelope Lake; however, the exact location of the test is unknown. Personnel interviews indicate that several areas of buried ordnance debris may also be present on or around the lake.

\subsubsection{South Flight Line Tomahawk}

South Flight Line Tomahawk consists of two locations where submunitions were deployed from Tomahawk cruise missiles from 1983 to 1985. The nature of the tests and the types of submunitions used in these areas are not known at this time.

\subsection{History AND Process KnOWLedge}

Historical information about the sites has been compiled from historical records research, personnel interviews, site visits, aerial photography, multispectral data, and preliminary geophysical surveys. Bomblets were tested during the Vietnam era for submunition dispersion coverage and CBU accuracy. When testing at Eglin Air Force Base was impaired by schedule conflicts, the TTR was promoted for its unique optical and radar capabilities as an alternate testing facility. Testing began at Mid Target, where a 1,000-ft by 1,500-ft CBU grid was constructed.

\subsection{Characterization DATA}

Previous characterization data are limited for CAU 408. Preliminary geophysical surveys have been conducted at Mid Target, SAC Target, and Antelope Lake to identify the locations of the bomblet target areas. No previous soil samples have been collected at the bomblet target areas. 
SAFER Plan - CAU 408

Section: Unit Description

Revision: 0

Date: October 2006

THIS PAGE INTENTIONALLY LEFT BLANK 
The DQO process is a seven-step systematic planning method used to plan data collection and field investigation activities for CAU 408, Bomblet Target Area. The seven steps of the DQO process presented in this report were developed according to the EPA Guidance on Systematic Planning Using the Data Quality Objectives Process (EPA, 2006). DQOs are designed to ensure that data collected will provide sufficient and reliable information to identify, evaluate, and technically defend the recommended corrective actions. Outputs from the DQO process will define the following: the objective of the data collection effort, the target population and conceptual site model (CSM), the most appropriate type of data to collect, the closure standards, and hold points where investigation findings will be reviewed with the Nevada Division of Environmental Protection (NDEP) and/or the U.S. Department of Energy, National Nuclear Security Administration Nevada Site Office (NNSA/NSO) to obtain a consensus for a path forward.

During DQO discussions for CAU 408, data needed to resolve decision statements were identified, criteria for data collection and analysis were defined and agreed upon, and the appropriate quality assurance (QA) / quality control (QC) required for data collection activities were assigned. The analytical methods and reporting limits prescribed through the DQO process and the data quality indicators (DQIs) for laboratory analysis, such as precision and accuracy requirements, are provided in more detail in Section 7.0 of this SAFER plan.

\subsection{SUMMARY OF DQO ANALYSIS}

\subsubsection{State the Problem (Step 1)}

Step 1 of the DQO process describes the problem to be studied and develops a CSM to gain a sufficient understanding of the problem.

CAU 408 is being investigated and closed because debris and potential contamination related to submunitions testing are present at known locations on the TTR. Additional information will be gathered to support the project goals. Submunitions will be located, and the extent of potential contamination will be verified.

The problem statement for CAU 408 is, "Additional information is required to verify existing information, confirm the existence of contamination and/or waste, and affirm the closure decision."

\subsubsection{Background Information}

CAU 408, Bomblet Target Area, consists of CAS TA-55-002-TAB2, Bomblet Target Areas, and is located on the TTR. The following sections present information on the physical setting, operational history, sources of potential contamination, and COPCs.

Physical Setting and Operational History - CAU 408 includes several areas located on the TTR where bomblet drops were conducted from the late 1960s to 1985. Details on the physical setting and operational history of CAU 408 are found in Section 2.0 of this report. 
Sources of Potential Contamination and COPCs - The bomblets, which may contain high explosives, are the source of potential contamination to the native surface/subsurface soil. In addition, bomblets on the South Antelope Lake bomblet area may contain DU. Soil contamination is not expected at CAU 408; however, this will be confirmed by collecting and analyzing soil samples. Based on process knowledge, the only COPCs are high explosives (all bomblet areas) and uranium (South Antelope Lake bomblet area).

\subsubsection{Conceptual Site Model}

The CSM is used to organize and communicate information about site characteristics. It reflects the best interpretation of available information and is based on historical documentation, personnel interviews, process knowledge, site visits, aerial photography, multispectral data, and preliminary geophysical surveys. The CSM describes the most probable scenario for current conditions at the site and defines the assumptions that are the basis for identifying appropriate data collection methods. Figure 2 graphically represents the CSM for CAU 408.

The primary CSM is considered the most probable scenario for current conditions at CAU 408. The CSM for CAU 408 assumes that submunition bomblets ranging in size from 2 to 4 inches that were dispensed from CBUs are present at the seven bomblet areas located on the TTR. Some previous cleanup of all submunition test areas is apparent but undocumented. An effective previous cleanup of 95 percent is assumed. For example, if 30,000 bomblets were dropped at Mid Target, approximately 1,500 may remain. While some miscellaneous ordnance debris (other than intact bomblets) may be located and removed during CAU 408 field activities, it is not considered to be part of the closure scope. The primary closure scope for CAU 408 is location and removal of intact bomblets at all locations and DU at South Antelope Lake.

The bomblets were designed to generate a minimal terminal velocity to impact surface targets and not to penetrate the ground surface. Therefore, they are assumed to be present on the ground surface to a maximum depth of $1 \mathrm{ft}$ below ground surface. Submunitions were constructed of ferrous metals and will be detectable by geophysical methods. Submunitions and debris may be deeper than assumed either by deeper penetration or by entering an animal burrow or crack in the ground; however, this situation is not anticipated. Submunitions buried to a depth of $1 \mathrm{ft}$ or greater are not considered a hazard to surface activities per U.S. Army Corps of Engineers guidance. In addition, interviews and preliminary geophysical surveys indicate that there is a significant potential for submunitions and debris to be present in disposal pits up to $10 \mathrm{ft}$ in depth located at SAC Target Location 1 and South Antelope Lake. These pits will be discernable using geophysical methods.

The horizontal boundaries of submunition test locations are assumed to be delineated by the furthest extent of submunition and debris from the drop locations. This extent will be evaluated to validate the CSM during field activities and will be modified as needed to maintain a minimum 50-ft submunition-free buffer zone. 


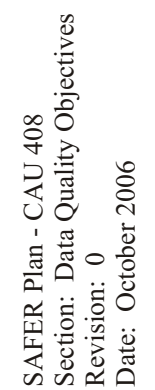

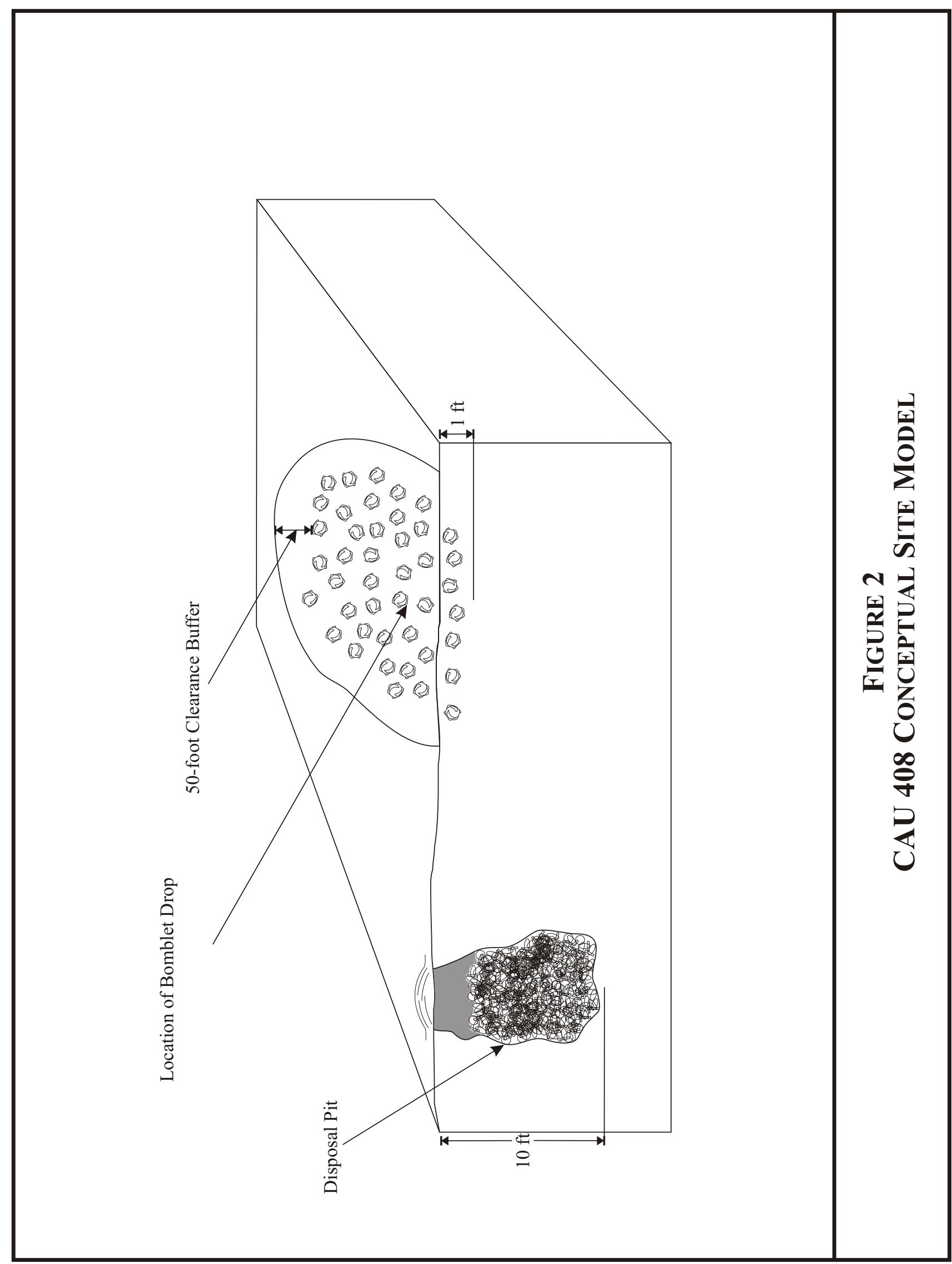


The proposed activities are based on the assumption that there are no COCs above action levels in the soil and no elevated levels of radiation that are unrelated to DU fragments present above free release criteria, as specified in Table 4-2 of the NV/YMP Radiological Control Manual (DOE/NV, 2004). This assumption will be verified by collecting soil samples. The primary CSM assumes that upon detonation of the bomblets, any hazardous constituents would be spent and would not impact the surrounding soil; however, physical hazards from unexploded bomblets are of concern. The majority of the tests used inert filler and no fuzing, or inert filler and live fuzing. Some tests involved live filler (high explosives) and live fuzing. All submunitions will be considered to be live until confirmed otherwise by qualified explosive ordnance disposal (EOD) personnel, or rendered inert.

At the South Antelope Lake bomblet area, submunition tests containing DU are known to have been conducted; however, the specific test locations have not been documented. A radiological survey of the entire lakebed will be conducted on South Antelope Lake to detect the presence of $\mathrm{DU}$, and the site boundaries will be delineated to define the lateral extent. If present, DU is expected to be found in discrete pieces with minimal soil impact. Verification of DU fragment clean closure will utilize field survey techniques. If radiological surveys indicated that more than 1 cubic foot of soil is impacted, verification samples will be collected and analyzed for isotopic and elemental uranium after the soil is removed. If significant areas of DU-impacted soil are present, or if areas of DU not related to CAU 408 activities are found, the CSM will be reevaluated, and the investigation-closure strategy may be revised as necessary.

If additional elements that are outside the scope of the CSM are identified during remediation, the situation will be reviewed, and a recommendation will be made as to how to proceed. In such cases, NDEP and NNSA/NSO will be notified and given the opportunity to comment on, or concur with, the recommendation.

\subsubsection{Identify the Goal of the Study (Step 2)}

Step 2 of the DQO process identifies the study questions.

The goal of the study for CAU 408 is to identify and clean-close all areas of submunition testing on the TTR. The DQOs will document a level of confidence related to the identification of areas where submunition testing was conducted. At the completion of CAU 408 closure activities, there will be a high degree of confidence that all areas of submunition testing have been identified and remediated.

CAU 408 study questions include:

- $\quad$ Have the site boundaries been adequately identified?

- $\quad$ Are submunitions present at the site?

- $\quad$ Are COCs present above action levels?

- $\quad$ Have the sites been clean-closed based on the CAU 408 criteria? 


\subsubsection{Identify Information Inputs (Step 3)}

Step 3 of the DQO process identifies the information needed, the sources of information, and sampling and analysis methods that can answer the study questions.

\subsubsection{Information Needs}

In order to confirm the CSM and determine the nature and extent of ordnance debris and contamination, data must be collected and analyzed using the following criteria:

- $\quad$ Data will be collected from locations most likely to contain ordnance and/or contamination.

- $\quad$ The analytical suite and field survey instruments selected and their associated detection limits will be adequate to detect COPCs at or below their action levels.

\subsubsection{Sources of Information}

Information needed to answer the study questions will be generated by field observations, with aerial and multispectral photographs, by conducting geophysical and radiological surveys, and by collecting soil samples for laboratory analysis.

Quantitative Data - Quantitative data measure the quantity or amount of a characteristic or component. These data require the highest level of QA/QC in collection and measurement systems because the intended use of the data is to resolve primary decisions and/or to verify closure standards have been met. Laboratory analytical data are considered quantitative.

Soil samples will be collected from both random and biased locations. Samples will be collected from locations likely to be contaminated using appropriate sampling methods. The locations likely to be contaminated include areas where bomblet drops occurred and areas where discrete pieces of DU are found. Soil samples collected from all bomblet areas will be analyzed for explosives. In addition, soil samples collected from the South Antelope Lake area will be analyzed for isotopic and elemental uranium. Samples will be submitted to analytical laboratories meeting the quality criteria stipulated in the QAPP (NNSA/NV, 2002). Validated data from analytical laboratories will be used to support DQO decisions. Sample collection and handling activities will follow standard procedures.

Semiquantitative Data - Semiquantitative data indirectly measure the quantity or amount of a characteristic or component. Inferences are drawn about the quantity or amount of a characteristic or component because a correlation has been shown to exist between the indirect measurement and the results from a quantitative measurement. The QA/QC requirements on semiquantitative collection and measurement systems are high but may not be as rigorous as for quantitative data. Semiquantitative data contribute to decision making but are not used alone to resolve primary decisions. Field-screening data are considered semiquantitative and will include geophysical and radiological surveys for CAU 408. The data will be used to guide investigations toward quantitative data collection. 
Geophysical surveys using electromagnetic and handheld instrumentation will be completed at CAU 408 submunition test locations to determine the extent of surface and shallow subsurface metallic debris and to identify potential areas of buried waste related to submunition test activities. 100 percent of all sites will be surveyed to ensure complete clearance. Geophysical survey techniques such as EM-61 metal detectors or hand-held instrumentation will be used. Geophysical anomalies that meet the CAU 408 criteria will be identified for further evaluation by EOD technicians, and will be removed if determined to be ordnance related to CAU 408 and rendered inert, if necessary.

Radiological surveys using gamma ray spectrometers and handheld instrumentation will be completed at South Antelope Lake to map areas with elevated gamma activity and to locate DU fragments related to testing of submunitions and to verify DU cleanup. The surveys will be completed using a gamma ray spectrometer system that will report, as a minimum, gross counts and the Protactinium-234m window from a multi-channel analyzer. Handheld radiological survey instruments will also be used to screen submunitions and debris for radiation in order to provide semiquantitative data that can be used to guide waste management activities.

Qualitative Data - Qualitative data identify or describe the characteristics or components of the site. The QA/QC requirements are the least rigorous on data collection methods and measurement systems for qualitative data. The intended use of the data is for information purposes, to refine conceptual models, and to guide investigations rather than resolve primary decisions. This measurement of quality is typically assigned to historical information and data where QA/QC may be highly variable or not known. Professional judgement is often used to generate qualitative data.

Visual observations during field visits and during remediation activities will be made to confirm the existence and identify the location of bomblets. Aerial photographs and multispectral photographs will also be examined to identify the location of the bomblet areas and disposal pits.

\subsubsection{Define the Boundaries of the Study (Step 4)}

Step 4 of the DQO process defines the target population and characteristics of interest, specifies the spatial boundaries and time constraints of that population pertinent for decision making, and determines practical constraints on data collection.

\subsubsection{Target Population}

The population of interest is ordnance and/or DU fragments located at submunition testing locations on the TTR, and soil containing COCs above action levels at bomblet testing locations.

\subsubsection{Spatial Boundaries}

The spatial boundaries include the areas where submunition tests were conducted, and where submunition testing debris was potentially buried. These are the areas most likely to contain bomblets based on historical knowledge and personnel interviews. The vertical boundary of the study is the ground surface to a depth of $1 \mathrm{ft}$ for testing locations, and the ground surface to a depth of $10 \mathrm{ft}$ for potential buried debris sites. The lateral boundary of the study will be modified as needed to maintain a minimum 50 -ft submunition-free buffer zone. If bomblets 
and/or contamination are identified outside these boundaries, the situation will be reviewed with NDEP and NNSA/NSO, and a determination will be agreed upon as to how to proceed.

\subsubsection{Time Constraints}

The study data should be relevant with the length of time allowed for by the SAFER process under the FFACO (FFACO, 1996). Data will be collected at times that meet the security and safety constraints of the TTR and at times when weather conditions allow adequate site access and safe working conditions. Remediation activities are currently scheduled to begin in Fiscal Year 2007. The Closure Report (CR) milestone deadline is June 30, 2008.

\subsubsection{Practical Constraints}

Other constraints that may affect the ability to collect data include the following:

- $\quad$ Approval of SAFER Plan and DQOs

- $\quad$ Equipment access and availability at the TTR

- $\quad$ Access restrictions at the TTR

- $\quad$ Weather conditions (e.g., snow, standing water)

- $\quad$ Other unsafe working conditions

\subsubsection{Develop the Analytical Approach (Step 5)}

Step 5 of the DQO process defines the population parameters, develops the decision rules for drawing conclusions from findings, and specifies the action levels.

\subsubsection{Population Parameters}

Each sample result within the population of interest will be compared to the action levels to determine the appropriate resolution to the decisions. A single soil sample result above the action level would cause a determination that a COC is present.

\subsubsection{Decision Rules}

If site boundaries are not delineated, then the area will be reevaluated, and the site boundaries will be modified as needed to include areas where submunitions are present. If submunitions are present, then they will be removed, rendered inert if necessary, and disposed, and soil samples will be collected from drop locations and analyzed for explosives. If DU fragments are present, then they will be removed and disposed, and the area will be radiologically surveyed to verify clean closure. Soil samples will be collected and analyzed for isotopic and elemental uranium as needed to verify DU cleanup. If contaminants are present in the soil above action levels, then additional samples will be collected to identify the extent of contamination. If it is technically feasible to remove the contamination, then the contaminated soil will be excavated and disposed, and verification samples will be collected to verify cleanup. 


\subsubsection{Action Levels}

The action levels for explosives and elemental uranium will correspond with the EPA Region IX PRGs for industrial soils. Soil samples will be collected and analyzed to verify clean closure of DU if soil contamination exceeds 1 cubic foot in volume. The action levels for isotopic uranium will be based on a dose rate of 25 millirem per year (mrem/yr) for radioisotopes. Cleanup of DU fragments will be verified using radiological screening methods. The radiological action level for solid media will be defined as the unrestricted-release criteria defined in the NV/YMP Radiological Control Manual (NNSA/NSO, 2004).

The measurement and analysis methods listed in the QAPP (NNSA/NV, 2002) are capable of measuring analyte concentrations at or below the corresponding action levels for each constituent.

\subsubsection{Specify Performance or Acceptance Criteria (Step 6)}

Step 6 of the DQO process specifies probability limits for false rejection and false acceptance decision errors and examines the consequences of making incorrect decisions. Setting acceptable limits on the likelihood of making decision errors requires the planning team to weigh the relative effects of threat to human health and the environment, expenditure of resources, and the consequences of an incorrect decision.

EPA's DQO guidelines state that if a judgmental sampling approach is used, quantitative statements about data quality will be limited to measurement error (EPA, 2006). Measurement error is influenced by imperfections in the measurement and analysis system. Random and systematic measurement errors may be introduced in the measurement process during physical sample collection, sample handling, sample preparation, sample analysis, and data reduction. If measurement errors are not controlled, they may lead to errors in making the DQO decisions.

In general, confidence in DQO decisions based on judgmental sampling results will be established qualitatively by:

- $\quad$ Developing CSMs

- $\quad$ Testing the validity of the CSMs based on investigation results

- $\quad$ Evaluating the quality of the data based on DQI parameters

\subsubsection{Decision Errors}

False Rejection - This decision error would mean deciding that submunitions and/or contamination are not present when they actually are present. The potential consequence of a false rejection decision error is an increased risk to human health and environment. The potential for a false rejection decision error is reduced by meeting these criteria:

- $\quad$ Thoroughly evaluating each submunition test location through visual inspections and review of geophysical and radiological survey data

- $\quad$ Completing a geophysical survey of 100 percent of the bomblet target areas and investigating anomalies that meet the CAU 408 criteria 
- $\quad$ Selecting the soil sample locations from areas most likely to be contaminated (i.e., impact areas of submunitions containing DU)

- $\quad$ Assessing the analytical and field survey results to ensure that all sample analyses and instrumentation have detection limits less than or equal to the corresponding action levels

- $\quad$ Assessing the data against the DQIs of precision, accuracy, comparability, sensitivity, and completeness, and collecting the appropriate QC samples as defined in the QAPP (NNSA/NV, 2002)

False Acceptance - This decision error would mean deciding that submunitions and/or contamination are present when they actually are not present. The potential consequence of a false acceptance decision error is increased costs and project duration. False acceptance errors are typically attributed to laboratory and/or sampling errors that could cause crosscontamination. To control against cross-contamination, decontamination of sampling equipment will be conducted according to established and approved procedures and only clean sample containers will be used. In addition, QC samples such as field blanks, trip blanks, laboratory control samples, and method blanks will be collected to minimize the risk of a false acceptance analytical result.

The potential for a false acceptance decision error will also be reduced by completing a geophysical survey and investigating all geophysical anomalies that meet the CAU 408 criteria (i.e., size, composition, and depth). The capability of the geophysical survey equipment to identify intact submunitions that meet the CAU 408 criteria will be accomplished by completing a geophysical prove out and survey QA.

\subsubsection{Develop the Plan for Obtaining Data (Step 7)}

Step 7 of the DQO process provides a sampling and analysis plan that meets the performance criteria and summarizes the approach to answer the study questions.

\subsubsection{Statistical Model}

Submunitions tests were conducted at Mid Target to assess ordnance and delivery package design. The aircraft were required to fly a specific flight line in the south-to-north direction for photographic documentation and radar acquisition. Therefore, submunitions at Mid Target are expected to be concentrated around the CBU grid with some longitudinal dispersion expected along the axis of aircraft travel. Lateral dispersion is expected to be minimal and concentrated along the flight line axis, resulting in a distribution along the flight path to be skewed in the long (late drop) direction, rather than symmetric about the target.

Submunitions tests were conducted at South Antelope Lake to assess material effects. The tests were restricted to the southern half of the lake so that concurrent tests on the northern half of the lake could continue unaffected. Therefore, submunitions are not expected to be located beyond the dry lake bed boundary or above the midline of the lake. However, EOD personnel will inspect the area up to 200 meters (m) beyond the boundary of the lake and up to $200 \mathrm{~m}$ north of the mid line of the lake. Submunitions and/or debris encountered along this boundary will be 
fully delineated, and the site boundary will be adjusted accordingly to maintain a 50-ft submunition-free buffer zone.

The statistical model assumes a skewed distribution along the flight line, such as a 3-parameter lognormal distribution, with a shift parameter that can be adjusted for the earliest expected occurrence of any object (i.e., drops that fell short) and a long tail simulating the distribution of drops that fell long (assuming a greater spread in long drops relative to the distribution of short drops).

A symmetric model and Laplace distribution is assumed for the lateral dispersion of submunitions, where the highest concentration of submunitions is found in the middle of the target. The probability of encountering no additional submunitions at the site boundary will be based on the density of submunitions encountered within the target zone and the length of the buffer zone desired. The resulting probability is based on a Poisson Process Model. Assuming an average of one submunition present per acre along the target perimeter, the likelihood of finding no bomblets beyond the 50 -ft buffer zone is at least 95 percent.

Although it is not anticipated, if the dispersion of bomblet locations does not follow any systematic decrease in density, a conditional probability approach will be used which utilizes parameters derived from the systematic distribution probabilities. This produces an estimated probability of encountering an object in the next sampling grid unit, given that no object has been encountered in the previous units along the same line.

\subsubsection{Summary of Scope of Work}

Submunition target areas will be identified for investigation and clearance. The target area boundaries will be modified as needed to ensure at least a 95 percent confidence for submunition cleanup. The site model boundary will be $50 \mathrm{ft}$ beyond the last observed submunition unit. The exact site boundary will be modified during closure activities, as needed, to ensure all areas containing submunitions are contained.

Geophysical and statistical models will be developed for CAU 408-related ordnance. The geophysical model will be based on the properties of specific submunitions tested at TTR and the results of geophysical surveys, and the statistical model will be based on distributional assumptions. The models will be evaluated and verified during field activities. The target areas will receive 100 percent coverage by manual and/or geophysical survey. All geophysical anomalies that meet the CAU 408-related criteria will be investigated, removed, and/or demilitarized. Submunition clearance will be verified by conducting post-cleanup verification (e.g., visual inspections and geophysical surveys after submunition clearance is completed).

DU fragments will be located by performing radiological surveys on South Antelope Lake. If found, the fragments will be removed and diposed, and radiological surveys will be performed to verify that the fragments have been removed. Soil verification samples will be collected if necessary. 
After submunitions are removed, soil samples will be collected and analyzed for explosives (all areas) and elemental and isotopic uranium (South Antelope Lake). If contamination is found above action levels, the contaminated soil will be excavated and disposed.

\subsection{RESUlts OF THE DQO ANALYSIS}

\subsubsection{Action Level Determination and Basis}

Based on site process knowledge, historical background information, site visits, preliminary assessment activities, and personnel interviews, no soil contamination is expected at CAU 408; however, the potential for soil contamination does exist due to testing activities conducted at the sites. The site will be clean-closed by removing and disposing of submunitions and DU fragments. Submunitions will be rendered inert by EOD personnel, if needed. Soil samples will then be collected for laboratory analysis to verify that no COCs are present. The action levels for explosives and elemental uranium will correspond with the EPA Region IX PRGs for industrial soils. The action levels for isotopic uranium will be based on a 25-mrem/yr dose rate for radioisotopes. Cleanup of DU fragments will be verified using radiological screening methods. The radiological action level for solid media will be defined as the unrestricted-release criteria defined in the NV/YMP Radiological Control Manual (NNSA/NSO, 2004).

\subsubsection{Hypothesis Test}

Section 3.1.6.1 of this report contains details on the hypothesis test and decision errors for CAU 408.

\subsubsection{Statistical Model}

Details on the statistical model for CAU 408 can be found in Section 3.1.7.1 of this report.

\subsubsection{Design Description/Option}

Biased and/or random soil samples will be collected and analyzed for explosives (all bomblet areas) and elemental and isotopic uranium (South Antelope Lake). Visible stains, if any, as well as radiological survey results will determine the location of biased soil samples. Otherwise, random soil samples will be collected.

\subsubsection{Conceptual Site Model}

The CSM is presented in detail in Section 3.1.1.2 of this report. Figure 2 illustrates the CSM. 
SAFER Plan - CAU 408

Section: Data Quality Objectives

Revision: 0

Date: October 2006

\section{THIS PAGE INTENTIONALLY LEFT BLANK}




\subsection{FIELD ACTIVITIES AND CLOSURE OBJECTIVES}

This section provides a description of and the rationale for characterization, waste removal, closure verification, site restoration, and waste disposal. The SAFER process is discussed in detail in the following subsections.

Prior to beginning the corrective action investigation and site closure fieldwork, the following activities will be completed:

- $\quad$ Preparation of National Environmental Policy Act documentation

- $\quad$ Preparation of a Site-Specific Health and Safety Plan

- $\quad$ Preparation of an NNSA/NSO Real Estate/Operations Permit

\subsection{Contaminants of Potential Concern}

The COPCs for CAU 408, based on site process knowledge and historical information, include explosives (all bomblet testing locations) and uranium (South Antelope Lake). No contaminants are expected to be present at concentrations above the action levels; however, this will be determined by verification sample results. Potentially affected media include the soil beneath or near bomblets or DU fragments. Verification samples will be collected from the soil to identify any COCs that may be present above action levels.

\subsection{REMEDIATION}

Based on the currently available process knowledge, historical data and documentation, aerial photography (historical and recent), personnel interviews, and site visits, no COCs are expected to be present at concentrations above the action levels at CAU 408. The site will be clean closed by removing all submunitions and DU fragments.

Geophysical surveys will be performed over the entire area of all the bomblet target areas to establish the target boundaries. The boundaries will be established $50 \mathrm{ft}$ beyond the last observed submunition unit. Evaluations will be conducted by EOD personnel to identify, remove, and demilitarize surface ordnance and debris. Geophysical surveys will also be conducted to identify subsurface anomalies. Any disposal pits that are identified will be excavated and removed. Soil samples will be collected and analyzed for explosives to verify that no COCs are present in the soil at concentrations above action levels.

Radiological surveys will be performed on South Antelope Lake to identify DU fragments. If found, DU fragments will be removed and disposed. Radiological surveys will be performed to verify that the DU fragments have been removed, and soil samples will be collected, if necessary, and analyzed for elemental and isotopic uranium to confirm that no COCs are present in the soil at concentrations above action levels. 
After soil sample analysis, any soil containing COCs above the action levels will be excavated and disposed at an appropriate landfill. Excavations will be backfilled with clean soil from an approved borrow source.

\subsubsection{Hold / Decision Points}

During closure activities, certain conditions affecting the project schedule and budget may require decisions prior to continuing work. The primary hold/decision points during the CAU 408 SAFER process includes the review of geophysical, radiological, and analytical data with NDEP and NNSA/NSO to confirm the closure approach.

In addition to the previously discussed hold/decision points, work may be temporarily suspended until the issue can be satisfactorily resolved if any of the following unexpected conditions occur:

- Conditions outside the scope of work are encountered

- $\quad$ Radiological screening yields results which require an upgrade in procedures

- Unsafe conditions or work practices not originally documented in the Site-Specific Health and Safety Plan and posing a threat to personnel, equipment, or the environment are encountered

- Other technical factors are encountered that require the preparation of a Record of Technical Change (ROTC) to the approved SAFER Plan

If any of these conditions occur, work will stop and NDEP and/or NNSA/NSO will be notified. Work will continue when a resolution has been agreed upon and a ROTC form, if required, has been approved by NDEP and NNSA/NSO.

\subsection{VERIFICATION}

The sampling techniques and analytical methods identified below will be used to verify closure and confirm the nature and extent of contamination at CAU 408.

Radiological Field Screening - A handheld radiological survey instrument will be used to evaluate the sites for the presence of radiological contaminated debris and/or soil. A Radiological Control Technician will be onsite during cleanup activities and will systematically screen the debris before it is removed from the site to verify that levels of radiation do not exceed free-release criteria specified in Table 4-2 of the NV/YMP Radiological Control Manual for free-release criteria (DOE/NV, 2004). In addition, if DU fragments are located, the surrounding soil will be screened to verify that the fragments were completely removed and that no residual radioactive contamination remains in the soil.

Soil Sampling - Soil samples will be collected for laboratory analysis to verify clean closure after submunitions and DU have been removed. Analytical results will be compared to the action levels specified in Section 3.1.5.3 of this report. 


\subsection{Closure}

Date: October 2006

The specific activities required to close CAU 408 are detailed in Section 4.2 of this report. Hold points and conditions that are outside the assumptions of this plan may impact the requirements for closure. Although no COCs are expected in the soil at concentrations above the action levels, soil samples will be collected to confirm this assumption, and soil removal activities are included in this SAFER plan as a contingency in the case that COCs are discovered. In general, the proposed activities for closure of CAU 408 include the following:

- $\quad$ Delineation of the boundaries of bomblet target areas and identification of disposal pits by geophysical surveys and visual inspections

- $\quad$ Removal of submunitions and debris

- $\quad$ Verification of submunitions clearance (e.g., visual inspections and geophysical surveys after submunition clearance is completed)

- $\quad$ Identification and removal of DU fragments

- $\quad$ Verification sampling and radiological screening of soil, and review of data to confirm closure

- If analytical data results indicate the presence of COCs at concentrations above the action levels, removal of contaminated soil and backfilling of excavations

- $\quad$ Preparation of a CR

\subsection{DURATION}

The schedule will require modifications if conditions exist that are outside the assumptions on which the schedule was developed. Flexibility has been placed in the project schedule to account for minor difficulties (e.g., weather, equipment breakdowns, personnel availability, TTR operations, and security constraints). NNSA/NSO will keep NDEP informed of any conditions that may impact the project schedule. Table 1 represents the preliminary proposed schedule duration for the field activities at CAU 408. The amount of days is contingent upon a variety of factors including site conditions, subcontractor availability, depth of contamination, and extent of ordnance surveillance activities.

Table 1. Duration of Field Activities

\begin{tabular}{||l|l||}
\hline \multicolumn{1}{||c|}{ ACTIVITY } & DURATION (DAYS) \\
\hline \hline Geophysical surveys & 32 \\
\hline Submunition/debris removal & 16 \\
\hline Submunition clearance verification & 12 \\
\hline Radiological surveys & 21 \\
\hline DU removal & 8 \\
\hline Verification sample collection & 16 \\
\hline
\end{tabular}


SAFER Plan - CAU 408

Section: Field Activities and Closure Objectives

Revision: 0

Date: October 2006

\section{THIS PAGE INTENTIONALLY LEFT BLANK}




\subsection{REPORTS AND RECORDS AVAILABILITY}

A daily report will be prepared during field activities. The report will summarize the daily activities, site personnel and visitors, health and safety issues, and any other relevant issues or problems. This report will be provided to the NNSA/NSO Task Manager.

Upon completion of closure activities, a CR will be prepared and will include the following sections and subsections:

- $\quad$ Introduction (Purpose and Scope)

- $\quad$ Closure Activities (Description of Corrective Action Activities, Deviations from the SAFER Plan as approved, Corrective Action Schedule as Completed, and Site Plan/Survey Plat)

- $\quad$ Waste Disposition

- $\quad$ Closure Verification Results (Data Quality Assessment and Use Restrictions)

- $\quad$ Conclusions and Recommendations

- $\quad$ References

- $\quad$ Supporting Documentation (Analytical Results for Verification Samples, Summary of Geophysical/Radiological Survey Results, Waste Disposition Documentation, and Modifications to the SAFER Plan)

The final CR will be submitted to NNSA/NSO and NDEP for review and approval. This SAFER Plan and the subsequent CR will be available in the NNSA/NSO public reading facilities in Las Vegas and Carson City, Nevada, or by contacting the NNSA/NSO Project Manager. NDEP maintains the official Administrative Record for all activities conducted under the auspices of the FFACO. 
SAFER Plan - CAU 408

Section: Reports and Records Availability

Revision: 0

Date: October 2006

THIS PAGE INTENTIONALLY LEFT BLANK 


\subsection{INVESTIGATION/REMEDIATION WASTE MANAGEMENT}

Waste from CAU 408 will be managed according to all federal and state regulations, U.S. Department of Energy orders, and National Security Technologies (NSTec) procedures. Potential waste types include sanitary waste and low-level radioactive waste.

During this project 55-gallon drums (or other approved containers such as rolloffs) may be used. All containers must be in good condition. The containers must always be closed while stored, unless waste is being added or removed. They must be handled in a manner that will not jeopardize the integrity of the container. Containers will not be filled above their specified weight capacity. After a container has been filled, the container will be locked. If a container is not completely filled to capacity at the end of workday, it will be locked and tamper-resistant tape will be placed over the container's hinge. Additional precautions include not filling drums more than 7/8 full, and not mixing waste types (e.g., personal protective equipment and decontamination water).

Appropriate labels and relevant information will be marked on each container with an indelible marker. The label marking must be legible and clearly visible for inspections. Pertinent data will be written on duct tape or a blank adhesive label that is applied to the side of the container. The following information will be included:

- Waste-tracking label

- $\quad$ Type of waste in the container

- $\quad$ Location from which waste was derived

- $\quad$ Date(s) that accumulation begins/ends

- If sampling is required, an “Awaiting Analysis” sticker after sampling has been completed

\subsection{WASTE MinimizATiON}

Waste generation will be minimized for the duration of the project by site workers adhering to the principles of the NSTec Waste Minimization and Pollution Prevention Program. Workers will take care to segregate waste from non-waste materials when possible and to avoid crosscontamination of waste streams.

\subsection{Potential Waste Streams}

The potential waste streams generated by closure of CAU 408 include sanitary waste and low-level radioactive waste. 


\subsubsection{Sanitary Waste}

Sanitary waste will be generated during closure of CAU 408, and will consist of ordnance debris that has been determined to be inert and free of hazards. Additionally, used personal protective equipment may be generated during closure activities. Sanitary waste may be disposed of in the TTR Sanitary Landfill or transported to the Nevada Test Site (NTS) for disposal.

\subsubsection{Low-Level Radioactive Waste}

Depending on field screening and soil sampling results, radiologically contaminated soil or debris may be present. Any soil or debris that is impacted above action levels will be removed and packaged as low-level radioactive waste and shipped to the NTS for disposal. In addition, any DU fragments that are found will be removed for disposal at the NTS. 


\subsection{QUALITY ASSURANCE/QUALITY CONTROL}

For the closure activities described in this plan, the overall objective is to collect accurate and defensible data to support the selection of and implementation of closure alternatives for CAU 408. The following sections discuss the collection of required QC samples in the field and QA requirements for laboratory/analytical data to achieve closure.

\subsection{SAMPle Collection Activities}

All samples will be collected according to established procedures (Bechtel Nevada [BN], 2000a and 2000b) and the QAPP (NNSA/NV, 2002). Field QC samples will be collected and analyzed to aid in determining the validity of sample results. The number of required QC samples depends on the type and number of environmental samples collected. The minimum number of QC samples to be collected and analyzed for this investigation is:

- $\quad$ Field duplicates (1 per 20 environmental samples, or 1 if less than 20 are collected)

- $\quad$ Field blanks (1 per batch of samples)

- $\quad$ Matrix spike/matrix spike duplicates (1 per 20 environmental samples, or 1 if less than 20 are collected)

Additional QC samples may be collected, based on site conditions, at the discretion of the Field Technical Lead. Field QC samples will be analyzed using the same analytical procedures used for environmental samples. The results of the QC sample analysis will be included in the CR.

\subsection{APPLICABLE LABORATORY/ANALYTICAL DATA QUALITY INDICATORS}

Clean closure of CAU 408 will require the collection and analysis of verification soil samples for explosives and for elemental and isotopic uranium. All laboratory data generated during closure activities will be reviewed by project personnel to ensure the data are usable and complete, according to the CAU 408 DQOs. In addition, as specified in the QAPP (NNSA/NV, 2002), the final data packages will be validated using applicable Organization Instructions (OIs). These include OI-2154.459 (BN, 2003) for validating inorganic chemical data. OI-2154.459 is based on the EPA Functional Guidelines (EPA, 1994).

DQIs are qualitative and quantitative statements that specify the data requirements of a project and include precision, accuracy, representativeness, completeness, and comparability. In addition, sensitivity has been included as a DQI for laboratory analysis. The performance criteria for each indicator have been selected on the basis of the intended use of the data, current field and analytical procedures, and instrumentation. For analytical laboratories under the EPA Contract Laboratory Program, precision and accuracy goals have been standardized. Laboratory QC samples used to measure the precision and accuracy of analytical procedures will be analyzed using the same analytical procedures used for environmental samples.

Table 1 provides established performance criteria for each of the DQIs and the impacts to the decision if the criteria are not met. The following subsections discuss each of the DQIs that will 
be used to assess the quality of laboratory data. Any deficiencies noted during the investigation that render the data quality unacceptable will be documented in the CR.

\section{TABLE 2. LABORATORY/ANALYTICAL DATA QUALITY INDICATORS}

\begin{tabular}{|c|c|c|}
\hline DQI & PERFORMANCE CRITERIA & $\begin{array}{c}\text { IMPACT ON DECISION IF } \\
\text { PERFORMANCE CRITERIA NOT MET }\end{array}$ \\
\hline Precision & $\begin{array}{l}\text { Variations between duplicates (field and } \\
\text { lab) and original sample should not } \\
\text { exceed analytical method-specific criteria. }\end{array}$ & $\begin{array}{l}\text { Estimated data within sample delivery group } \\
\text { (SDG) will be evaluated for their usability. If } \\
\text { data are determined to be unusable, data shall } \\
\text { not be used in decision, and completeness } \\
\text { will be assessed. }\end{array}$ \\
\hline Accuracy & $\begin{array}{l}\text { Laboratory control sample results and } \\
\text { matrix spike results should be within } \\
\text { analytical method-specific criteria. }\end{array}$ & $\begin{array}{l}\text { Estimated data within SDG will be evaluated } \\
\text { for its usability. If estimated data are biased } \\
\text { low and below the decision threshold, the } \\
\text { data shall not be used in decision and } \\
\text { completeness criteria will be assessed. }\end{array}$ \\
\hline Sensitivity & $\begin{array}{l}\text { Detection limits of laboratory instruments } \\
\text { must be less than action level for COCs. }\end{array}$ & $\begin{array}{l}\text { Cannot determine if COCs are present at } \\
\text { levels of concern, thereby investigation } \\
\text { objectives cannot be met. }\end{array}$ \\
\hline Completeness & $\begin{array}{l}\text { 100\% of samples must be submitted to the } \\
\text { laboratory, } 100 \% \text { of the requested } \\
\text { analyses must be performed, } 100 \% \text { of } \\
\text { critical a analytes must be determined to be }_{\text {alid, and } 80 \% \text { of non-critical analytes }} \\
\text { must be determined to be valid. }\end{array}$ & $\begin{array}{l}\text { 1) Decision of whether extent of } \\
\text { contamination has been bounded cannot be } \\
\text { determined. Impacts to decisions will be } \\
\text { assessed. } \\
\text { 2) Decision of whether COCs above action } \\
\text { levels remain in soil cannot be determined. } \\
\text { Impacts to decisions will be assessed. }\end{array}$ \\
\hline Comparability & $\begin{array}{l}\text { Equivalent samples analyzed using same } \\
\text { analytical methods, same units of } \\
\text { measurement, and detection limits must } \\
\text { be used for like analyses. }\end{array}$ & Inability to use data collected. \\
\hline Representativeness & $\begin{array}{l}\text { Correct analytical method performed for } \\
\text { appropriate COCs: valid data reflects } \\
\text { appropriate target population. }\end{array}$ & $\begin{array}{l}\text { Cannot identify COCs or estimate } \\
\text { concentration of COCs; therefore, cannot } \\
\text { make decision(s) on target population. }\end{array}$ \\
\hline
\end{tabular}

${ }^{\mathrm{a}}$ Critical analytes are those analytes most likely present in the target population, which have been identified through process knowledge of similar sites and historical documentation.

\subsubsection{Precision}

Precision measures the reproducibility of data under a given set of conditions. It is a quantitative measurement of the variability of a population of measurements compared to their average value. Precision applies to parameters sampled and analyzed in duplicate. One duplicate sample will be collected per set of 20 or fewer verification samples. All duplicate samples will be collected from the same medium and analyzed for the same set of analytes as verification samples. The precision of the analytical results will be assessed by calculating relative percent difference (RPD) for a verification sample and its duplicate sample results. A RPD of less than or equal to 30 percent indicates acceptable precision (NNSA/NV, 2002).

\subsubsection{Accuracy}

Accuracy measures the nearness of a measured or calculated value of a parameter to the true value of that parameter. The closer the measurement is to the true value, the more accurate the 
measurement. Accuracy will be assessed by examining the percent recovery of laboratory control and spiked samples. A percent recovery within the range of 70 - 130 percent indicates satisfactory analytical accuracy (NNSA/NV, 2002).

\subsubsection{Representativeness}

Representativeness is a qualitative measure of the degree to which the sample data accurately and precisely represents a characteristic of a sample population or environmental condition. This will be attained by ensuring that the sample locations, analytical parameters, analytical methods, sampling protocols, and sample handling all meet the project-specific objectives.

\subsubsection{Comparability}

Comparability is a qualitative measure that expresses the confidence that one data set can be compared to another. It will be achieved by using standardized field sampling procedures and same analytical methods for sample analysis. All samples will be collected using approved methods (BN, 2002a and 2002b). Sample results will be reported in standard units to allow for comparison of the data.

\subsubsection{Completeness}

Completeness is a quantitative measure of data quality expressed as the percentage of valid data obtained that satisfies the project-specific requirements. Since a limited number of samples will be collected for both waste characterization and verification of closure, 100 percent of the data collected needs to be of acceptable quality to maintain acceptable QA/QC standards.

\subsubsection{Sensitivity}

Sensitivity is the capability of a method or instrument to discriminate between measurement responses representing different levels of a variable of interest. This indicator is determined from the value of the standard deviation at the concentration level of interest. It represents the minimum difference of concentration that can be distinguished between two samples with a high degree of confidence. Sensitivity must be sufficient to detect contaminants at or below decision levels. Sensitivity will be achieved by analyzing all samples using the appropriate EPAapproved analytical laboratories, methods, and instruments. 
SAFER Plan - CAU 408

Section: Quality Assurance / Quality Control

Revision: 0

Date: October 2006

\section{THIS PAGE INTENTIONALLY LEFT BLANK}




\subsection{REFERENCES}

BN, see Bechtel Nevada.

Bechtel Nevada. 2002a. “Sampling Chain of Custody”, Organization Instruction OI-2152.100. Las Vegas, NV.

Bechtel Nevada. 2002b. “Soil Sampling”, Organization Instruction OI-2152.108. Las Vegas, NV.

Bechtel Nevada. 2003. “Inorganic Data Verification and Validation, Revision 1,” Organization Instruction OI-2154.459. Las Vegas, Nevada.

DOE/NV, see U.S. Department of Energy, Nevada Operations Office.

EPA, see U.S. Environmental Protection Agency.

FFACO, see Federal Facility Agreement and Consent Order.

Federal Facility Agreement and Consent Order. 1996 (as amended). Agreed to by the State of Nevada, U.S. Department of Energy, and U.S. Department of Defense.

NNSA/NV, see U.S. Department of Energy, National Nuclear Security Administration Nevada Operations Office.

U.S. Department of Energy, National Nuclear Security Administration Nevada Operations Office. 2002. Industrial Sites Quality Assurance Project Plan. DOE/NV--372, REV 3. Las Vegas, Nevada.

U.S. Department of Energy, Nevada Operation Office. 2004. Nevada/Yucca Mountain Project Radiological Control Manual, Revision 5. DOE/NV/11718--079. Las Vegas, NV.

U.S. Environmental Protection Agency. 1994. Laboratory Data Validation Functional Guidelines for Evaluating Inorganic Analyses, EPA/540/R-94/083. Washington, D.C.

U.S. Environmental Protection Agency. 2006. Guidance on Systematic Planning Using the Data Quality Objectives Process, EPA QA/G-4, EPA/600/R-96/055. Washington, D.C.

U.S. Environmental Protection Agency. 2004. Region IX Preliminary Remediation Goals. San Francisco, CA. 
SAFER Plan - CAU 408

Section: References

Revision: 0

Date: October 2006

THIS PAGE INTENTIONALLY LEFT BLANK 
SAFER Plan - CAU 408

Section: Appendix A.1

Revision: 0

Date: October 2006

\section{APPENDIX A.1}

\section{PROJECT ORGANIZATION}


SAFER Plan - CAU 408

Section: Appendix A.1

Revision: 0

Date: October 2006

THIS PAGE INTENTIONALLY LEFT BLANK 
The U.S. Department of Energy, National Nuclear Security Administration Nevada Site Office (NNSA/NSO) Federal Sub-Project Director for Industrial Sites is Kevin Cabble, and his telephone number is (702) 295-5000.

The identification of the project Health and Safety Officer and the Quality Assurance Officer can be found in both the Field Management Plan and the Site-Specific Health and Safety Plan.

However, personnel are subject to change, and it is suggested that the NNSA/NSO Federal SubProject Director be contacted for further information. The Task Manager will be identified in the Federal Facility Agreement and Consent Order Monthly Activity Report prior to the start of field activities. 
SAFER Plan - CAU 408

Section: Appendix A.1

Revision: 0

Date: October 2006

THIS PAGE INTENTIONALLY LEFT BLANK 
SAFER Plan - CAU 408

Section: Library Distribution List

Revision: 0

Date: October 2006

\section{LIBRARY DISTRIBUTION LIST}


SAFER Plan - CAU 408

Section: Library Distribution List

Revision: 0

Date: October 2006

THIS PAGE INTENTIONALLY LEFT BLANK 
U.S. Department of Energy

National Nuclear Security Administration

Nevada Site Office

Technical Library

P.O. Box 98518, M/S 505

Las Vegas, NV 89193-8518

U.S. Department of Energy

Office of Scientific and Technical Information

P.O. Box 62

Oak Ridge, TN 37831-0062

Southern Nevada Public Reading Facility

c/o Nuclear Testing Archive

P.O. Box 98521, M/S 400

Las Vegas, NV 89193-8521

Manager, Northern Nevada FFACO

Public Reading Facility

c/o Nevada State Library \& Archives

Carson City, NV 89701-4285
1 (Uncontrolled)

1 (Uncontrolled, electronic copy)

2 (Uncontrolled, electronic copies)

1 (Uncontrolled, electronic copy) 
SAFER Plan - CAU 408

Section: Library Distribution List

Revision: 0

Date: October 2006

THIS PAGE INTENTIONALLY LEFT BLANK 